Arie W. Zwiep

\title{
Christ, the Spirit and the Community of God
}

\author{
Essays on the Acts of the Apostles
}

[Christus, der Geist und die Gemeinde Gottes. Studien zur Apostelgeschichte.]

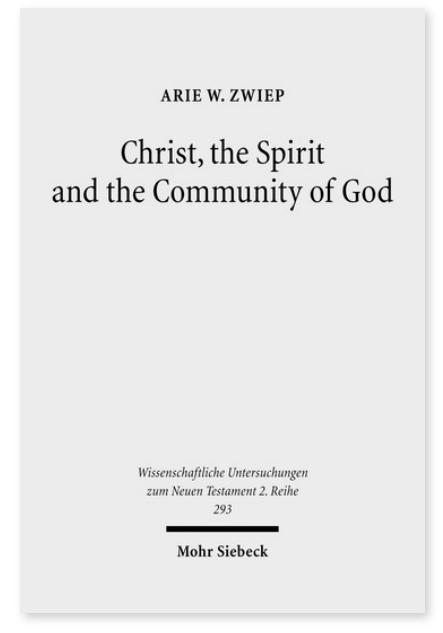

2010. XVIII, 237 Seiten. WUNT II 293

ISBN 978-3-16-151636-8

DOI 10.1628/978-3-16-151636-8

eBook PDF 74,00€

ISBN 978-3-16-150675-8

fadengeheftete Broschur $74,00 €$
Veröffentlicht auf Englisch.

Arie W. Zwiep versammelt textkritische, exegetische und biblisch-theologische Studien zur Apostelgeschichte. Diese handeln vor allem von deren Anfangskapiteln im Gesamtzusammenhang des Christentums im ersten Jahrhundert und seiner Umwelt. Die Studien beinhalten Abhandlungen zu Christi Himmelfahrt im frühjüdischen und frühchristlichen Kontext, zum Tod und zur Ersetzung des Judas Ischariot und zu den verschiedenen Betrachtungsweisen bezüglich seines Todes. Zudem geht es um die Rolle von Judas und den Juden in der Geschichte des Antisemitismus, um Pfingsten und die Ausgießung des Heiligen Geistes, frühchristliches Gemeindeleben, die Auferstehung und Erhöhungschristologie in Petrus' Pfingstrede und Lukas' besondere Betrachtung von Paulus in Bezug auf die 12 Apostel in Jerusalem.

Arie W. Zwiep Geboren 1964; 1996 Promotion; 2017-20 Director Graduate School of Religion and Theology an der Fakultät Religion und Theologie der Vrije Universiteit Amsterdam; dort seit 2020 Prodekan, seit 2021 Professor für Hermeneutik. https://orcid.org/0000-0003-0126-1563
Jetzt bestellen:

https://mohrsiebeck.com/buch/christ-the-spirit-and-the-community-of-god-9783161516368?no_cache=1 order@mohrsiebeck.com

Telefon: +49 (0)7071-923-17

Telefax: $+49(0) 7071-51104$ 